BOGDAN LEVYK,

Lviv Polytechnic National University (Lviv, Ukraine)

e-mail:levykbs@gmail.com,ORCID 0000-0001-5100-0834

MARIUSZ SKORNIEWSKI,

Catholic University of Lublin (Lublin, Poland)

e-mail:mskorn@o2.pl,ORCID0000-0001-8307-3122

\title{
THE ARMENIANS OF LVIV IN MANAGEMENT OF THE POLISH UNDERGROUND ORGANIZATION "UNION OF ARMED STRUGGLE" IN 1939-1940-s
}

\begin{abstract}
The work is devoted to the creation of "live" images of the history based on the materials of the particular historical sources (Ya. Daschkevych). The authors have endeavored to establish the circumstances of sentencing the members of the Polish underground organization and publicized the standard schemes of the Soviet investigation and justice in the 30-40-s of the $20^{\text {th }}$ century by examining the personal criminal cases of three participants of the Polish underground organization "Union of Armed Struggle", namely the Armenians of Lviv Zigmund Chrzontovskyi (engineeragronomist), Adam Bogdanovych (canon of the Armenian Catholic Chapterhouse in Lviv) and Cheslav Kaniak (prior of Dominican Cathedral). Summarizing the materials, interrogation protocols of the arrested and witnesses, the authors have demonstrated as the Soviet investigative authorities and court completely rejected human rights, appropriated the confiscated material assets. Furthermore, the great authority of the Armenian Catholic Church in Lviv and high level of patriotism among its representatives are depicted.
\end{abstract}

Key words: Soviet occupation of Lviv; "Union of Armed Struggle"; the Armenians Catholics; Zigmund Chrzontovskyi; Adam Bogdanovych; Cheslav Kaniak.

\section{Introduction}

An urgent issue of modern historical studies is a personification of the past that permits to present a gallery of famous and significant persons for the national history as well as to recreate historical circumstances and events that contradict the official history through studying the historical persons' internal world and facts from their biographies. A special influence occurs, when the unknown factual sources, particularly, the archival documents, an access to which have been forbidden till recently, enter into the scientific circulation. For instance, it was with the issue of Polish anti-Soviet underground that acted in Lviv during 1939-1941. The authors managed to reveal the circumstances of conviction of 14 members of command belonged to the Polish underground organization "Union of Armed Struggle" by the Soviet authorities on the base of the criminal case № P-30031 in the previous article (Levyk, Skorniewski, 2019). To continue the study we have a goal to apply to the personal cases of the underground group's members - the Armenians of Lviv, namely Zigmund Chrzontovskyi, Adam Bogdanovych and Cheslav Kaniak who were connected with the financial support of "Union of Armed Struggle".

A commitment to the biographical studies of the Armenians of Lviv within the context of the Polish anti-Soviet struggle is our contribution to the issue of "Ukrainian historical field" (Osipyan, 2004; Hayuk, 2019) as well as the resistance to some endeavors of the Polish researchers to "privatize" the history of Armenian colonies in Ukraine. On the other hand, consideration of the documents has refuted the Polish armed struggle within the context of Ukrainian national organizations' activity of the previous presentations, for instance, in the Russian issue "Ukrainian nationalistic organizations during the Second World War. Documents: into 2 volumes. V.1: 1939-1943" that was published by ROSSPEN in 2012 (Artizov (ed.), 2012).

\section{Methods}

The content and structure of the criminal cases as well as the special character of archival records were studied by the methods of source heuristic; archival source criticism, in particular textual analysis and information reconstruction were applied. The main method of the study was historical and biographical method with the elements of prosopography. The elements permitted to depict an ordinary man "who acted in the usual spheres: personal, human connections, made moral choices, had private life and could be represented in the full human meaning, not one-sided or in a conjectured way, but objectively and truly" (Starovoytenko, 2006: 8).

The famous Ukrainian historian Ya. Daschkevych wrote about the meaning of prosopography. According to him, it expanded deepened biographical material through taking into account personal and general human features in the history. Nevertheless, he considered that the most crucial and valuable feature of prosopography was veracity and objectivity of information, recreation of a celebrity in a conjunction with the positive and negative sides of biography, creation of "live" historical images based on the materials of the particular sources (Dashkevych, 1997).

Research and Results

Elzbeta Kotarska, the daughter of executed Lieutenant Colonel Vladyslav Kotarsky (nickname "Friend"), Com- 
mandant of the First Eastern District of Lviv, initially wrote about the process of fourteen. Elzbeta had constantly applied for the Red Cross of the USSR with the request to inform about the fate of his father since the beginning of 1960-s. The authorities of the KGB of the USSR decided to keep silence. Only at the beginning of the 1990-s, E. Kotarska could read the archival criminal case № P30031. Later, the relatives of the other executed Polish patriots could obtain such opportunity. As a result, Ms. Kotarska added the criminal case with the reminiscent of other underground fighters who managed to stay alive, with family photos (Kotarska, 1998). The bibliographical information about the leaders of "Union of Armed Struggle" was given by the well-known Polish historians Gzegosh Mazur and Ezy Vegersky (1997). Piotr Kolakovsky (2002) conducted a historical research about the activity of the Polish underground military structures in the Eastern Galicia.

A fact that an Armenian bond bank in Poznan financed the Polish underground anti-Soviet organization was proved by Elzbeta Kotarska (1998); however she did not mention any particular names. Nevertheless, the criminal case P-30031 saved the names of Zigmund Chrzontovskyi and Adam Bogdanovych for the history. All information about the prior of the Dominican Cathedral Cheslav Kaniak, an Armenian due to his origins, was removed from the case. He was withdrawn from the case under unknown procedural reasons, transferred from Lviv to Kirovograd, where an investigation was undertaken and as the other members of a group sentenced to capital punishment.

Consequently, having presented for consideration by the scientific community the criminal cases of men who financed the Polish underground in Lviv in 1939-1941, we have restored the historical justice and complemented the Armenian context in the history of Lviv and Ukraine.

Chrzontovskyi Zigmund (Zigizmund) Yanovych was born in 1889, specialty engineer-agronomist, lived in Lviv, Tarnavskogo Str. 61, flat 3.

He graduated from Warsaw High Agronomic School in 1926. During 1914-1916 he served in the Austrian army in the rank of junior Cavalry Officer, Lieutenant of reserve. He did not serve in the Polish army, and had worked for the House of Lviv as an engineer-agronomist since 1935.

His wife was Chrzontovska Irena 37-years old, a housewife. The daughters: Barbara (born in 1922) and Irena (born in 1923) were schoolchildren of Lviv's gymnasium 21. The native brothers: Rudolf 68 years old and Tadeusz 57 years old, the last one worked as a forest engineer. The native sisters: Janina Zbrozek 58 years old, a pharmacist, lived in Konsky city and Elena Biasevych 60 years old a pharmacist, also lived in Konsky city of Keltsynsky district.

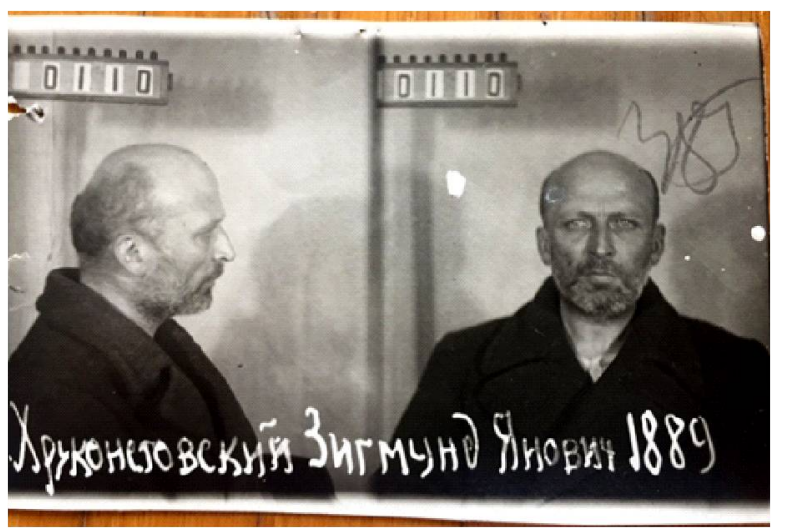

A photo of the engineer Chrzontovskyi Zigmund Yanovych in prison, (made in the prison 2 in April 1940 , belonged to the UNKVD in Lviv district)
The criminal case 523 of Chrzontovskyi Z. Ya. was started in connection with his arrest in April 1940. An order about the preventive measure was issued before the arrest by the junior Lieutenant of the KGB Yakovlev in March $30^{\text {th }} 1940$. He was kept in the prison 2 at the address: Zamarstynivska Str. 9 and was in the cell 65 since April $7^{\text {th }}$, 1940. He was questioned by Libenson, Bardakov, Bendersky on the $6^{\text {th }}, 11^{\text {th }}, 13^{\text {th }}, 16^{\text {th }}, 20^{\text {th }}, 23^{\text {rd }}$ of April; by the detectives Kozlov, Gudkov, Kantserov on the $9^{\text {th }}, 16^{\text {th }}, 25^{\text {th }}$, $30^{\text {th }}$ of May 1940; by the head of investigation commission on the $19^{\text {th }}$ of June; by an unknown on the $22^{\text {nd }}$ of June 1940.

A search of the place of residence was performed by the junior Lieutenant Bogdanov, the head of $2^{\text {nd }}$ department of $3^{\text {rd }}$ branch of the UNKVD in Lviv district, member of the NKVD of the USSR senior Lieutenant Libenson. During the search 3000 of golden polish zloty in banknotes of 50 hidden in a bathroom behind a mirror were seized. Moreover, 800 zloty were hidden behind a mirror of a dressing table in a room. Man's and woman's watches, a golden bracelet, two rings with black stones, bracelets, cufflinks, brooches, camera, silver coins, chains were seized. Everything was described in a protocol of search and the acts were transferred to the financial department of the UNKVD in Lviv district for storage ${ }^{1}$.

Chrzontovskyi was arrested in a safe flat, the owner of which was Bronislava Dashkevych.

He was questioned by the members of the NKVD of the USSR, particularly by the head of the $1^{\text {st }}$ department of the GU NKVD of the USSR Meshyk and the senior detective of the GU NKVD of the USSR Libenson on March 31st. He confessed that was a member of UAS and joined the underground independently. Initially, he helped the Polish officers and refugees; a group was created in November 1939 and included Daskevych Bronislava, Lysynskyi Zdislav, Kovalskyi Marian. He named the person who donated money to the group, among them were Golender Anton, Kuznytskyi, they worked for the House of Lviv. A connection with UAS was conducted via Lysynskyi Zdislav. Lysynskyi had lived in Chrzontovskyi's apartment as a tenant till the mid of January 1940 and had a nickname "Fox" and "Zdislav". According to Chrzontovskyi the head of the organization was the Colonel V. Zebrovskyi. Furthermore, he named the Colonel Vitse-Zarchevskyi, nickname "Nero" among the other authorities of UAS. The other persons were known under the nicknames "Romek", "Pine", "Yanek", "Emil".

Moreover, he named the addresses of the safe houses and the passwords to them:

1. Yaponska Str. 5, the password "To Adam".

2. The square of Unia Lubelskaya (nowadays Gutsulska Str.) 3, stall, the first door right. The password "To Romek".

3. The square of St. Ura 6, stall left, the password "To Adam".

4. Pelchynskogo Str. (he could only demonstrate).

5. Tarnavskogo Str. 65, the password "To Wojciech".

$\mathrm{He}$ was in charge of the financial support in the organization. He distributed money to the heads of the organization under the order from the Colonel Zebrovskyi. The money was distributed in Polish zloty and Russian rubles, namely "Romek" obtained 15 thousand, "Yanek" - 15 thousand, "Chanke" Daschkevych - 10 thousand, "Pine" - 10-

1 Сектор архівного забезпечення (САЗ) УСБУ у Львівській області. Архівна кримінальна справа (АКС) № П-30031. (Archive Supply Sector (ASS) the Security Service of Ukraine in Lviv district. Archive criminal case). T. 2. C. 175.

SKHID No. 2 (166) March-April 2020 
15 thousand. The money was hidden at home behind a mirror of a dressing table, behind a mirror in bathroom, and in the books. The conspirators supposed him to be a treasurer of the head office.

The next questioning was on April $11^{\text {th }}, 1940$, during the interrogation he confessed that gave gold instead of money to the head of intelligence "Pine" about $1 \mathrm{~kg}$., Sverzbynskyi - 600 gr. The priest $A$. Bogdanovych was put into the room during the questioning; he proved that Chrzontovskyi knew where the gold was hidden². After that Chrzontovskyi named the prior of the Dominican Cathedral, the father Cheslav Kaniak who hid the jewelry between the window frames and in the sealed cellar of the monastery. The detective of the NKVD of the USSR Libenson made a conclusion that Chrzontovskyi had initially diverted suspicion from the fathers Bogdanovych and Kaniak. Nevertheless, after the confrontation with the father Bogdanovych, he gave additional testimony and began to discover the other members of the organization. The following members were named:

1. Myronovych Mykolay, the nickname "Dog", "Mykolay", was the head of the press and propaganda department.

2. The father Panas, the nickname "Senkal", a military Chaplain, Colonel

3. The priest Tsenskyi from the Church of St. Mary Magdalena at Leon Sapega Str.

4. The father Kisil, a priest of the military hospital.

5. Mitselskyi, the nickname "Rey", a Major, commanded the Western district in Lviv.

6. Kotarsky, the nickname "Friend", a LieutenantColonel.

7. Dzekanovsky Karol-Yan, the nickname "Karol", "Nadolskyi", "Charovin", "Chervina", "Karvin", "Kruk", "Olgerd Dzevonskyi", a Lieutenant-Colonel, a deputy of the commandant of UAS Zebrovskyi.

8. Chmelevskyi, the nickname "Yulek", a cashier of the head office.

9. "Vitold" - a Commander of the obvod ${ }^{3}$ in the Eastern district.

10. "Roslan" - a Commander of the obvod in the Eastern district.

11. "Falko" - a Commander of the obvod in the Eastern district.

12. "Boruta" - a Commander of the obvod in the Eastern district.

Due to the arrested, all the commanders came to a meeting to their commander Kotarskyi (the nickname "Fried") at Shymonovytcha Str.10. Chrzontovskyi was a deputy of the commander of the Eastern district Vladyslav Kotarskyi for some time. Furthermore, he named the following persons:

13. "Shtepan", an Adjutant of the Lieutenant Colonel V. Kotarskyi.

14. Lesevych Dozia worked for the radio station and had a connection with Bronislava Dashkevych.

\footnotetext{
2 During the interrogation of the father canon Adam Bogdanovych after 21 p.m. on April 11 th, 1940 , it was revealed for the detective of the GU NKVD of the USSR Libenson that the second person who knew about the hidden gold of Poznan bond bank in Dominican Monastery and Cathedral was Z. Chrzontovsky. The third person was the Roman Catholic priest Joseph Panas, who had managed to throw himself from the staircase and killed himself at the time when he was escorted to an interrogation in the building of the UNKVD. His death was kept in secret by the staff of the UNKVD. Nevertheless, a Polish woman who was a cleaner noticed a body at the yard of the UNKVD while she was cleaning the floor from blood. Later, the members of UAS knew the information.

${ }^{3}$ It is equal to a battalion in quantity.
}

15. Stronskyi, the nickname "Tadeusz", a courier from Paris. He stayed at Chrzontovskyi's apartment three times.

16. "Stanislav" - a courier from Paris, he came from Budapest, was in Stanislav and Lviv, planned to visit Bilostock and Vilno.

17. Levytskyi Anton, the nickname "Ruk", a chief of the head office, he was replaced by the Major Vitse-Zarchevskyi, nickname "Nero".

18. Pershke, a woman, relative of Devonskyi where he lived.

19. Galban - a professor of Lviv University who was in charge of coding and gathering the political information.

20. Berkovskyi, the nickname "Berek", a captain, a deputy of the Major Martsyniak, the nickname "Emil", the head of the provinces.

21. Gerchenreder was in charge of armament.

22. Luchkevych, an engineer, member of the Polish People's Party, lived in the district of radio plant.

23. Tabysch - a lawyer, member of the Social Democratic Party, lived at Paderevskogo Str.5.

24. Schyrek - a lawyer, member of the Polish Socialist Party (PSP) ${ }^{4}$, he did not have one arm.

25. Bzesytskyi Marian, the nickname "Hawk", lived at Zyzynska Str.9, was an assistant of Chrzontovskyi, who recruited him to the organization in January 1940. He sold the golden jewelry on the illegal market.

Chrzontovskyi personally wrote on a page of the protocol that the father Bogdanovych informed him at the presence of a detective that he had told everything, consequently, he had decided to give the true testimony.

Some interrogation protocols where the persons testified against Chrzontovskyi ${ }^{5}$ were added to the criminal case.

1. The interrogation protocol of Bzesytskyi Marian Stanislavovych, lived at Zyzynska Str.9, fl.4, born in 1908. It is known from the protocol that Bzesytskyi had the nickname "Hawk" and was recruited by Chrzontovskyi in February 1940. They met at the entrance to the Church at Bernardynskaya Square, where Chrzontovskyi asked about the prices on gold. He obtained the answer that on the illegal stock exchange $1 \mathrm{gr}$. was sold for 60 rub. They were acquainted with each other according to the cooperative work for the financial department where Marian Bzesytskyi was a clerk. Chrzontovskyi offered to sell a golden chain and ring, invited to his house at Tarnavskogo Str. where confessed that he had a lot of golden jewelry that he had an intention to sell. He explained that the gold belonged to the underground Polish organization. An oath of allegiance to UAS was given by Bzesytskyi to Chrzontovskyi in his apartment. Bzesytskyi or "Hawk" was disabled, he did not have a leg, and therefore he was above suspicion. He obtained gold from Chrzontovskyi, the nickname "Plomenchyk" two or three times a week. He had sold about $1.5 \mathrm{~kg}$. of gold and obtained the revenue approximately 4 thousand Soviet rubles ${ }^{6}$. Moreover, an apartment of "Hawk" was used as a safe house. Chrzontovskyi visited it under the guise

\footnotetext{
$\overline{{ }^{4} \text { The arrested presented Lychkevych, Tabysch and Schyrek as }}$ members of the political council (committee) of UAS and informed that they occasionally obtained money in the sum of 5-7 thousand zloty.

${ }^{5}$ Сектор архівного забезпечення (САЗ) УСБУ у Львівській області. Архівна кримінальна справа (АКС) № П-30031. (Archive Supply Sector (ASS) the Security Service of Ukraine in Lviv district. Archive criminal case). T. 2.

${ }^{6}$ The testimony can be doubted. According to the prices on gold of 60 rub. for 1 gr., he should have obtained 90 thousand Russian rubles (1500 gr. ${ }^{*} 60=90000$ rub.).
} 
of a Russian language teacher for Bzesytskyi's sister Rosalia and brother Vladyslav who lived with him. The password for entrance was "to the engineer". When Bzesytskyi, "Hawk" was arrested, approximately $1 \mathrm{~kg}$. of gold was left that was later given to his acquaintance Sudlits Vladislava, who lived at Gavke Bassaka Str.43.

"Hawk" informed that he was a mediator for the meetings with a professor of the university. Skliarchyk, a professor 60 years old, a member of the National Democratic Party (The Polish National Organization), he established a civil underground organization in Lviv. Chrzontovskyi negotiated with the professor Skliarchyk about the integration of the organization to UAS.

2. The interrogation protocol of K.T. Dzekanovskyi of 07.04.1940. According to his testimony, Chrzontovskyi was a member of UAS, deputy of the head of the Eastern district, member of the financial commission, who used a safe house of Bronislava Dashkevych, the nickname "Chanka" at Tarnavskogo Str.27. He actually lived at Tarnavskogo Str.61. Chrzontovskyi participated into the design of organizational structure. The distinctive features: the golden teeth. Dzekanovskyi was acquainted with Chrzontovskyi via the priest Joseph Panas.

3. The interrogation protocol of A.I. Sverzbynskyi ${ }^{7}$ of 08.04.1940. He named the commander of the $1^{\text {st }}$ Eastern district, Lieutenant Colonel Kotarskyi (the nickname "Friend") and his deputy Lieutenant Z. Chrzontovskyi (the nickname "Plomenchyk"), who simultaneously was a member of a control financial commission, among the heads of the organization.

4. The interrogation protocol of the priest of the Armenian Catholic Church Adam Bogdanovych of 11.04.1940. According to his testimony, Zigmund Chrzontovskyi was included into a financial commission, visited his apartment with the father Panas with the aim of taking money for UAS.

5. The interrogation protocol of M.K. Myronovych of 11.04.1940. He gave testimony that Chrzontovskyi was a member of UAS, had the nickname "Plomenchyk" and was a deputy of the commander of the Eastern district of Lviv, a member of financial commission.

6. The second interrogation protocol of A.I. Sverzbynskyi of 13.04.1940. The detectives Prys, Gudkov of the investigation department of the UNKVD in Lviv district and the detective Libenson of the department of the NKVD of the USSR obtained the following information:

"The financing of the organization was via the priest of the Armenian Catholic Church Adam Bogdanovych and the engineer Zigmund Chrzontovskyi. The priest Bogdanovych Adam Stanislavovych (an Armenian) via the other Armenian Chrzontovskyi Zigmund Yanovych gave 60000 Soviet rubles to the courier Tadeusz Stronskyi who transferred the sum for the necessities of UAS. The father Bogdanovych also transferred money in American currency into the cashbox of UAS organization, particularly to the cashier Chmelevskyi via Chrzontovskyi and the priest Panas. 200000 of Soviet rubles, 50000 zloty, and additionally 4000 zloty were transferred from the cashbox of POWO the Polish Organization for Fatherland Liberation as the

\footnotetext{
7 Sverzbynskyi Anton Josephovych, the nickname "Fox" supervised the intendant sector (economic) of the organization of UAS that included financial and monitoring department. He lived at Kyschynska Str. (nowadays Karmeluk Str.) 11 in Lviv. He used an apartment at Kurkova Str. (nowadays M. Lysenka Str.) 25 as a safe house. Sverzbynskyi was not mentioned in the bibliographical dictionary of Lviv Conspiracy 1939-1944, issued by the authors Gzegosh Mazur and Ezy Vengerskyi in the publishing house "Unia" in Krakow in 1997.
}

ISSN 1728-9343 (Print)

ISSN 2411-3093 (Online) rest of finance ${ }^{8}$ during February 1940. UAS organization had access to the jewelry in a pawn shop in Poznan that was transported to Lviv by a head of the pawn shops' department. Eventually, the jewelry, in the total amount of 5 boxes, was transferred into the Dominican Monastery and Armenian Catholic Cathedral for storage. The jewelry might be accepted by the father Panas and engineer Chrzontovskyi. It was approximately estimated at 2 million rubles. The jewelry was hidden into two places. A place where the jewelry was sealed knew the priest Panas, engineer Chrzontovskyi and the father Bogdanovych. The organization planned to sell the jewelry and the money that would be raised, transferred into the cashbox of UAS. The gold in weight was directed into the underground work. The cashier Chmelevskyi obtained 500 gr. of gold before his arrest, initially he gave $500-550 \mathrm{gr}$. of gold to the head of intelligence, nickname "Pine", $432-434 \mathrm{gr}$. of gold to the priest Tsenskyi. The gold could be taken from the monastery only by the engineer Chrzontovskyi. There were 2300 rubles and 20000 zloty in the cashbox at the moment of Chmelevskyi's arrest. 200000 rubles were transferred to the authorities of UAS, 40000 - to intelligence and the rest to the lower departments in February 1940. The financial commission planned the expenditure of 300000 Soviet rubles in March 1940"9.

The detective, junior Lieutenant Gudkov ordered the indictment to Chrzontovskyi Zigmund Yanovych of committing offences under article 54-2 (armed rebellion preparation for seizure of power) and under article 54-11 (participation into a counterrevolutionary organization) according to Criminal Code of Ukrainian SSR. Chrzontovskyi pleaded guilty. Chrzontovskyi was not questioned from May to July 1940. The confrontation between Kotarsky Petro Frantsevych and Chrzontovskyi Zigmund Yanovych was on August $19^{\text {th }}, 1940$. The both confirmed that the first was a commandant of the Eastern district of UAS in Lviv and the second was his deputy.

The detective Gudkov organized the confrontation between Chrzontovskyi and Sverzbynskyi Anton Josephovych on August $20^{\text {th }}, 1940$. The both provided incriminating testimonies one against the other, and had entirely enumerated the functions performed in the organization of UAS. The interpreter Yasechek was present during the interrogation.

Consequently, the criminal guilt of Chrzontovskyi Z. Ya., in committing the crimes, was completely proven according to the criminal procedural norms under articles 54-2 and 54-11 of Criminal Code of Ukrainian SSR.

$\mathrm{He}$, as the other trial P-30031 defendants, was sentenced to capital punishment on 19.11.1940.

After the end of the formal term after sentence (during which the defendants had appealed to the Court of Cassation, the cassations were considered and rejected ( $L e-$ $v y k$, Skorniewski, 2019), sentence was carried out at 23:30 on February $24^{\text {th }}, 1941^{10}$.

\footnotetext{
8 In January 1940, POWO with all members (approximately 300 persons) joined UAS - Union of Armed Struggle. The Colonel Zayanchkovskyi, who was in charge of a regiment on the border near Glyboke village before the war, was a leader of the organization. He was captured by the Soviet Army in September 1939; however he could pretend to be a soldier and easily escaped from a camp near Busko town.

9 Сектор архівного забезпечення (САЗ) УСБУ у Львівській області. Архівна кримінальна справа (АКС) № П-30031. (Archive Supply Sector (ASS) the Security Service of Ukraine in Lviv district. Archive criminal case). T. 2. C. 68-71.

10 Сектор архівного забезпечення (САЗ) УСБУ у Львівській області. Архівна кримінальна справа (АКС) № П-30031.
}

SKHID No. 2 (166) March-April 2020 
The daughters of Chrzontovskyi: Irena Krasinska and Barbara Dobrovolska tried to obtain information about their father's fate; the archival case had the proper notes.

Chrzontovskyi Zigmund Yanovych was rehabilitated by the decision of Lviv Region Prosecutor's Office on June 23 $3^{\text {rd }}$, 1993

Adam de Roshko Bogdanovych (1898-1941), born in Dolyniany village Grodek-Yagellonskyi region Lviv district, an Armenian according to the origins, however was educated as a Catholic and patriot in the family ${ }^{11}$. 17-year old entered to a brigade of the Polish legionnaires. He had decided to enter to a seminary after his injury, became a chaplain in 1920. He worked in metropolis of Krakow with the metropolitan Adam Sapieha and was ordained a priest at 24. In 1921 he became a secretary and chaplain of the archbishop Joseph Teodorovych and simultaneously occupied a position of vicar in the Armenian Catholic Church.

He worked in a religion library in Warszawa, knew Armenian and Latin for performing a liturgy. While being in Warszawa, he had studied philosophy at university for year and a half. He returned to Lviv in 1923. He tried to hold a liturgy in Latin in lieu of Armenian, however obtained an order from Lviv to perform a liturgy exclusively in Armenian. He started preparation for his PhD thesis in a university's library, nevertheless, left for Great Britain by invitation after some months. One year later, he returned to Lviv where started to work as a chancellor of curia, cathedral administrator and secretary of archbishop. All the duties were burdensome for the father Adam; he was interested in pastoral and scientific work. The priest Bogdanovych obtained a duty to perform religious ceremonies in Gorodents of Stanislaw region every two weeks of each month and the rest held in Lviv from the second half of 1927. The father Adam had such schedule till 1935. Simultaneously, he was an editor of Lviv Armenian Newspaper "Grygoriana".

He became a canon of the Catholic Armenian Chapterhouse in Lviv in 1935. The father Adam had halted his theological studies and PhD work since that period. The canon Bogdanovych had great trust to the Armenian congregation. He was invited to Tarnov, Krakow, Zakopane, Poznan, Lublin and many other places of inter-war Poland. He often organized recollections for the youth. The parishioners especially visited his sermons. Adam Bogdanovych was an authoritative figure; a lot of people came for his advice. The archbishop Joseph Teodorovych died on December $4^{\text {th }}, 1938$. Everybody waited for the election of a new head of the Armenian Catholic Church of the Eastern Galicia, a lot of parishioners expected an appointment of the father Bogdanovych. By contrast, the priest Dioniziy Kaetanovych, a vicar of chapterhouse was elected. The father Bogdanovych gathered the youth around himself in the organization "The Youth of Christ".

He lived at Skarbovskaya Str. 14/12 (nowardays Lesia Ukrainka Str.) fl.3 near the cathedral. The head of the $3^{\text {rd }}$ department of the UNKVD in Lviv district, Lieutenant Makarov determined as a preventive measure (arrest)

\footnotetext{
(Archive Supply Sector (ASS) the Security Service of Ukraine in Lviv district. Archive criminal case). T. 1. C. 225-235.

11 Bogdanovychi was a famous Armenian family in Lviv who had a lot of priests, lawyer, merchants, and prominent figures of culture. Having the origins in Kamenets-Podolsk, they settled in Stanislaw when Kamenets was captured by Turks and after that they moved in Lviv. There are 50 representatives of the noble family rest in peace in 8 tombs and singular graves in the cemetery-museum Lychakiv. The Armenian Church in Galicia was enriched by 11 Bogdanovychi - fathers, vicars, priors, canons, deans, administrators, archdeacons, etc. during the period $18-20^{\text {th }}$ centuries.
}

against the priest Adam Bogdanovych on April $2^{\text {nd }}, 1940$. The father Bogdanovych was secretly arrested without official notification to the relatives and Armenian Catholic Church. Keeping secret, the authorities of the UNKVD did not have any search at the accommodation.

The testimony against the father Adam Bogdanovych gave the courier from Paris Stronskyi Tadeusz, the nickname "Tadeusz" who was a guest of Bogdanovych and settled in apartment belonged to the Armenian Cathedral. The father Adam helped Stronskyi with codes and decoded the instruction 1 from the general Sikorskyi about Union of Armed Struggle creation on the territory of the Western Ukraine. The territory had a name Minor Poland, the southeast territories of Poland, seldom the Eastern Galicia in the instruction.

The first interrogation was on April $2^{\text {nd }}, 1940$. Bogdanovych Adam Stanislavovych confessed that was a member of the underground organization and had a nickname "Dog". He agreed to give testimony exclusively about himself. He became a member of the organization in December 1939

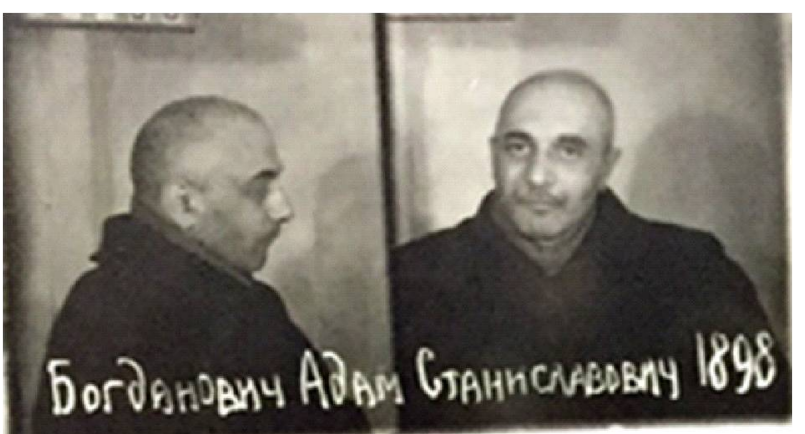

\section{A photo of the the father Adam Bogdanovych in prison, (made in the prison 2 in April 1940, belonged to the UNKVD in Lviv district)}

The member of the NKVD of the USSR Libenson provided a night interrogation that lasted from 3 a.m. on April $11^{\text {th }}, 1940$ to 7.30 a.m. on April $12^{\text {th }}$. During interrogation the father Bogdanovych informed that he knew the Polish officer Edgar Lazarskyi who was an Adjutant of Tadeusz Stronskyi. Lazarskyi stayed at a house belonged to the Armenian Catholic Church. His brother Artur Lazarskyi came with him in autumn 1939. The father Adam Bogdanovych acquainted with Tadeusz Stronskyi at that time. The brothers Lazarskyi went abroad in October 1939. In December 1939 Tadeusz Stronskyi visited a flat of Bogdanovych, explained that he came from Paris and brought an instruction as a representative of the immigration government in Paris. The text of the instruction was coded in the form of numbers on the silk material. The father Bogdanovych helped Stronskyi to decode the text. The instruction was addressed to the general Marian ZegotaYanuschaitis (the nickname Zegota) ${ }^{12}$ about the Polish

\footnotetext{
12 Zegota-Yanuschaitis Marian-Joseph (1889-1973), the first surname Yanuschaitis, had the nicknames "Yan Zegota", "Karpinskyi", "Ezy Stryi", "Vitold Ravich", "Zegota", a Divisional General of PR. He was born near Czestochowa in a large family in April $3^{\text {rd }}, 1889$. His father was a teacher; mother was from the family of Staschevskye. The primary education obtained in Russian schools. During 1900-1905 he studied at private gymnasium in Czestochowa. Later he studied in the machine-building department at Polytechnic University in Lviv. He began to study at the Agricultural Academy in Dubliany in 1909, and graduated from it with a specialty of agronomist-engineer in 1912 . He stayed at university and provided the scientific work in the department of botanic, morpho-
} 
underground organization establishment. It was offered to create four military districts - Warszawa, Lviv, Krakow and Bialystock districts. The establishment of the military underground organization was begun. Yanuschaitis should become a leader of Lviv district, the general Andersen should take Krakow district.

The father Adam Bogdanovych confessed that he had organized a meeting between Paris courier and the Colonel V. Zebrovskyi. The canon Bogdanovych acquainted with the Colonel Zebrovskyi at the apartment of the priest Kvaschynskyi who was his neighbor.

Stronskyi left Lviv in January 1940. The father Bogdanovych came to an apartment of the priest Panas and confessed that he was a member of UAS and asked about financial help for the organization the same month. He offered to have a conversation with a rich man who planned to leave Lviv and proposed him the money return abroad in the case if he left all his capitals for the needs of organization. An authoritative person should be found for the conversation and the father Adam agreed to perform that role. A meeting was at Dominikan square; consequently the organization obtained 500 thousand zloty.

The Lieutenant Colonel of PR, deputy of UAS commandant, nickname "Korvin", Karol Dzekanovskyi visited Bogdanovych and asked to influence on the commandant V. Zebrovskyi to cancel a premature military backslash against the Soviet authorities, as he considered that it would lead to the ultimate human toll and elimination of the organization. The father Bogdanovych refused to answer a lot of questions during the interrogation.

The senior Lieutenant of the NKVD of the USSR, security officer E. Libenson questioned Adam Bogdanovych more often and longer.

The detective Gudkov presented the investigative materials in order of article 200 of Criminal Procedural Code of Ukrainian SSR for information to all 14 prisoners, including the father A. Bogdanovych on September 21-27 th 1940. The detective Gudkov made an indictment with accusation of the persons in the imputed crimes under articles 54-2 and 54-11 of Criminal Code of Ukrainian SSR on October $9^{\text {th }}, 1940$. The detective had evaluated the expropriated gold, jewelries, platinum, silver, diamonds, precious stones, watches of Poznan bond bank in 15 million rubles ${ }^{13}$.

Bogdanovych Adam Stanislavovych as well as Zigmund Chrzontovskyi and the other participants of "Group 14" were sentenced to capital punishment under articles 54-2 and 54-11 of Criminal Code of Ukrainian SSR, the sentence was performed on February $24^{\text {th }}, 1941$. His sister's son Evstachyi Lazarskyi from Krakow tried to obtain information about the fate of Adam Bogdanovych, the archival case had the proper notes.

Bogdanovych Adam Stanislavovych was rehabilitated by the decision of Lviv Region Prosecutor's Office on June $23^{\text {rd }}, 1993$

The Polish Armenians Catholics raised question about the beautification of father Adam Roshko Bogdanovych as a martyr for the faith in 2009 . The petition was sent to the patriarch Nerses Bedros the $19^{\text {th }}$.

logy and physiology under the guidance of the professor Severyn Kzemenevskyi. By the end of 1908, he entered the Polish paramilitary organization - Polish Military Union (PMU) was a member of the head office, instructor in Lviv. He was a founder of Polish Army organization in Dubliany, the new title was PMF

${ }^{13}$ Сектор архівного забезпечення (САЗ) УСБУ у Львівській області. Архівна кримінальна справа (АКС) № П-30031. (Archive Supply Sector (ASS) the Security Service of Ukraine in Lviv district. Archive criminal case). Т. 2. С. 199. Додаток № 2. C. $1-68$.

ISSN 1728-9343 (Print)

ISSN 2411-3093 (Online)
Kaniak Cheslav Avgustovych, born in Lviv in 1892.

$\mathrm{He}$ was a prior of Dominican monastery and cathedral in Lviv. Graduated from the university in Rome, he became a priest in 1915. The father Kaniak became a prior of Dominican monastery since November 1939. The monastery had land in amount of 400 morgen $^{14}$, small shoe factory, garment factory and printing house.

There were two charity organizations "Rosary" and "Renewal" in Dominican cathedral, the last was under the management of the prior Kaniak during 1938-1939. The organizations helped the deprived Polish children, refugees from Poland. "Renewal" was established on the initiative of the father Kaniak and included 50 women who collected charity among the inhabitants of Lviv. Cheslav Kaniak took a responsible attitude towards the gold as to the private property of people of Poznan that he was entrusted to store. The prior Cheslav Kaniak was connected with the Armenian bond bank "Mouns Pius" in Lviv. The mentioned bank had its office in Poznan.

His sibling Joseph Kaniak, 58 years old, professor, lived in Jaroslav.

UAS members gave to Cheslav Kaniak the treasures in the number of 5 boxes with the gold items for storage that were hidden on the territory of Dominican monastery and in the cathedral. The testimony was given by the father Bogdanovych and Z. Chrzontovskyi on April 11 $1^{\text {th }}, 1940$. The fact was a reason for Cheslav Kaniak's arrest on April $14^{\text {th }}, 1940$. An order for the arrest was prescribed only on April $19^{\text {th }}, 1940$. The criminal case was started by the detective of the NKVD of the USSR Libenson. The order was approved by the head of the UNKVD in Lviv district Kozlov.

The arrested father Cheslav was questioned on April $14^{\text {th }}, 1940$. During the interrogation the priest A. Bogdanovych was put into the room that provided testimony that the father Cheslav Kaniak stored the treasures of the organization. The last one confessed that he stored the treasures, however, could tell the place only at the direction of the engineer Z. Chrzontovskyi who deposited them. The interrogation was performed by the deputy of a head of the UNKVD in Lviv district, Lieutenant of state security Krymian in the presence of a member of the NKVD of the USSR, senior Lieutenant of state security Libenson ${ }^{15}$.

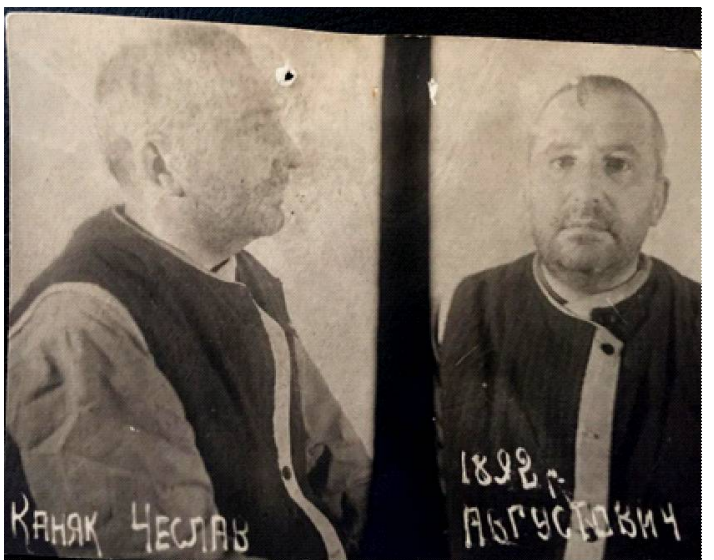

A photo of the father Cheslav Kaniak in prison, (made in the prison 2 in April 1940, belonged to the UNKVD in Lviv district)

\footnotetext{
${ }^{14} \mathrm{~A}$ unit of land measurement equals to 0,56 ha.

15 Сектор архівного забезпечення (САЗ) УСБУ у Львівській області. Архівна кримінальна справа (АКС) № П-30031. (Archive Supply Sector (ASS) the Security Service of Ukraine in Lviv district. Archive criminal case).
}

SKHID No. 2 (166) March-April 2020 
The NKVD authorities expropriated the gold from the monastery on April $14^{\text {th }}, 1940$. The one hiding place was sealed in a cellar's wall; the other was between the window frames in the cathedral according to the protocol of search. The search was provided under the authority of the senior Lieutenant of state security Libenson and others members of the NKVD. The gold was delivered to the financial department of the NKVD in Lviv after 2 months, on June $11^{\text {th }}$, 1940. The authorities of UAS were unaware of the gold confiscation from Dominican cathedral and monastery for two months. Nobody asked about the jewelry in the Armenian cathedral as they were not connected with UAS. We put a fragment of the interrogation of Cheslav Kaniak of 9.05.1940. The interrogation began at 11.20:

"The treasures were escorted to Lviv by the worker of Poznan's pawn shop Stanislavskyi due to the order of the bank director Kot. The arrived gold and jewelry were recorded for Chrzontovskyi. Cheslav Kaniak distributed them to the priest Joseph Panas and engineer Chrzontovskyi. Kaniak gave testimony that the gold and jewelry received his predecessor the prior Zukevych Konstantyn. Stanislavskyi had a written document according to which the head of Poznan's pawn shop Tselichovskyi offered the father Kaniak to give jewelry and gold on demand of Stanislavskyi".

A copy of Chrzontovskyi's interrogation protocol of 9.05.1940 was in the criminal case of Cheslav Kaniak, where he informed that he had knew from the Roman Catholic priest Panas about the storage of gold and jewelry of Poznan's pawn shop in the monastery of Dominican cathedral provided by the priest Cheslav Kaniak or the father Cheslav. A lawyer, worker of Poznan's bond bank told the priest Panas about the gold. The priest Panas, Chrzontovskyi and lawyer came to the prior Kaniak with an offer to distribute stored gold for the needs of the Polish underground organization in January 1940. The father Cheslav Kaniak agreed. Some kilos of gold were distributed in the period from January to April 1940. The distribution was not recorded and performed according to the written demand. The engineer Chrzontovskyi transferred the gold via the Adjutant "Romka" and the head of intelligence "Pine" to the Colonel Zebrovskyi (the nickname "Bug"). The prior Cheslav Kaniak gave the gold only to the priest Panas and the engineer Chrzontovskyi. The cashier Chmelevskyi was in charge of control of the gold distribution in the organization, he weighted the gold before acceptance and distribution.

Ch. Kaniak was indicted under article 54-2 (armed rebellion preparation for seizure of power) and under article 54-11 according to Criminal Code of Ukrainian SSR on May $9^{\text {th }}, 1940$. The senior detective of the UNKVD in Lviv district was the senior political instructor Novikov I.V.

The interrogation of Cheslav Kaniak of May 22 nd, 1940 : "The head of Poznan's pawn shop Tselichovskyi brought 5 big boxes of gold and jewelry (rings, bracelets, broaches, watches, chains) in Lviv to hide them from the German army on September $24^{\text {th }}, 1939$. The owners had no time to ship them abroad, therefore they hoped for the Armenian bank Mons Pius in Lviv. Nevertheless, the Soviet authorities closed all private and Polish banks. The board of directors of Poznan's bond bank made a fast decision to store one part of gold in Dominican cathedral where the Armenian monks were, and the second part was put into the Armenian Catholic cathedral for storage. There was a big bale except the boxes. Four men unloaded the boxes. The gold was given to the commandant of the monastery Zukevych. The boxes were hidden in a monastery".

The priest Cheslav Kaniak denied his participation into UAS organization, as he did not have any nickname, did not take any oaths during the interrogation of May $24^{\text {th }}$, 1940. On May $25^{\text {th }}, 1940$, Chrzontovskyi gave testimony that the priest Kaniak Cheslav, who stored the gold of Poznan's bond bank, had agreed to distribute the treasures for the needs of the Polish organization - Union of Armed Struggle at the presence of the priests Panas and Bogdanovych. Consequently, we had found that Cheslav Kaniak was not a member of the organization; however, he was closely connected with its finance and activity.

The priest $A$. Bogdanovych confirmed during the interrogation of May $27^{\text {th }}, 1940$ that the priest Kaniak Cheslav had agreed to distribute the treasures and gold belonged to Poznan's bond bank for the needs of the Polish underground organization - Union of Armed Struggle since January 1940.

During the interrogation of the prior Cheslav Kaniak of May $28^{\text {th }}, 1940$, the priest Bogdanovych was put into the room, and provided testimony that the priest Kaniak knew that the gold, which he distributed, was used for financing of the organization, and that he also knew the Roman Catholic priest Panas.

There were no records in the criminal case about the investigation from the end of May till the second half of August. Nevertheless, it was a record of August 21 $1^{\text {st }}, 1940$ that the indictment of $\mathrm{Ch}$. Kaniak was returned from Kiev to Kirovograd for the additional investigation with the demand to finish the case till September $6^{\text {th }}, 1940$. Obviously, the father Cheslav Kaniak was escorted to Kirovograd from June to September. He was kept into the internal prison 1 of the UNKVD in Kirovograd; the head of the prison 1 was the Lieutenant of state security Grytsenko. According to the medical examination of October $23^{\text {rd }}, 1940$, he was recognized to be healthy. His fingerprints were taken and he was photographed.

The investigation was provided by the detective of the UNKVD Atamaniuk in Kirovograd. The arrested was planned to be escorted to Odessa, as he was recorded under the military prosecutor of Odessa military district, to be sentenced by the military tribunal that could have organized a closed meeting without a lawyer and witnesses, or the case could be sent to Moscow for "The Special Meeting" in that case the court hearing would have a distant character.

The case description was performed by the senior detective of investigation team, sergeant Netchypurenko. He started the preliminary investigation the same day.

During the interrogation of 4.10.1940, Ch. Kaniak recognized that he had given treasures for the needs of the Anti-Soviet organization; however, he was not a member of that organization. He was acquainted with the materials of investigation on the same day that meant that the preliminary investigation was complete and the case would be transferred to the prosecutor's office and presented in court. The material evidence was absent in the case as well as a search protocol of the expropriated gold.

The detective made the indictment on October $30^{\text {th }}$, 1940. The indictment stated that Kaniak Ch.A. was a member of Union of Armed Struggle, the Polish underground Anti-Soviet organization. He hid the treasures belonged to Poznan's bond bank, that was a part of a system of the municipal bond bank, in Dominican monastery and distributed gold for the needs of UAS. The testimony against him was given by the priest Bogdanovych Adam S. and the engineer Chrzontovskyi Zigmund Ya., with whom the confrontation was conducted.

The prosecutor of Kirovograd district approved the indictment and gave it the power of sentencing paper on November $25^{\text {th }}, 1940$. The case was directed to the court of Kirovograd district. The defendant was kept in prison. 
The court of Kirovograd district issued the sentence about capital punishment for Kaniak Cheslav Avgustovych under articles 54-2 and 54-11 of Criminal Code of Ukrainian SSR at 15.15 on November $29^{\text {th }}, 1940$. The head of the court was Bryskin, the secretary Cherevko. The court did not take into consideration the application of the lawyer Medvynska to reclassify article 54-2 (armed rebellion preparation for seizure of power) into 54-4 (giving support for the international bourgeoisie) of Criminal Code of Ukrainian SSR. The case was being heard at the closed meeting.

The defendant could address to Supreme Court of the USSR for appealing the sentence during 5 days after the judgment had been delivered, and also to file a clemency petition to the Presidium of the Supreme Council of the USSR. The lawyer on behalf of Ch. Kaniak appealed to the Court of Cassation to the Supreme Council of the USSR that via the Prosecutor's office of the USSR entered to the Supreme Council of the USSR.

The Prosecutor's office of the USSR confirmed that the cassation did not deserve attention and the sentence was approved on December $17^{\text {th }}, 1940$. The indictment was made by the prosecutor of the $1^{\text {st }}$ department USO $P$. Lebedev and approved by the prosecutor of the USSR L. Yachenin.

The court panel of the Supreme Council of the USSR included Topchyi, Fedotiev, Rojfe upheld the sentence on December $30^{\text {th }}, 1940$. Simultaneously, the lawyer appealed to the Supreme Council of the USSR for clemency to Ch. Kaniak on December $6^{\text {th }}, 1940$. The Presidium of the Supreme Council of the USSR upheld the sentence on March $17^{\text {th }}, 1941$. Head of the Presidium of the Supreme Council of the USSR was I. Golikov.

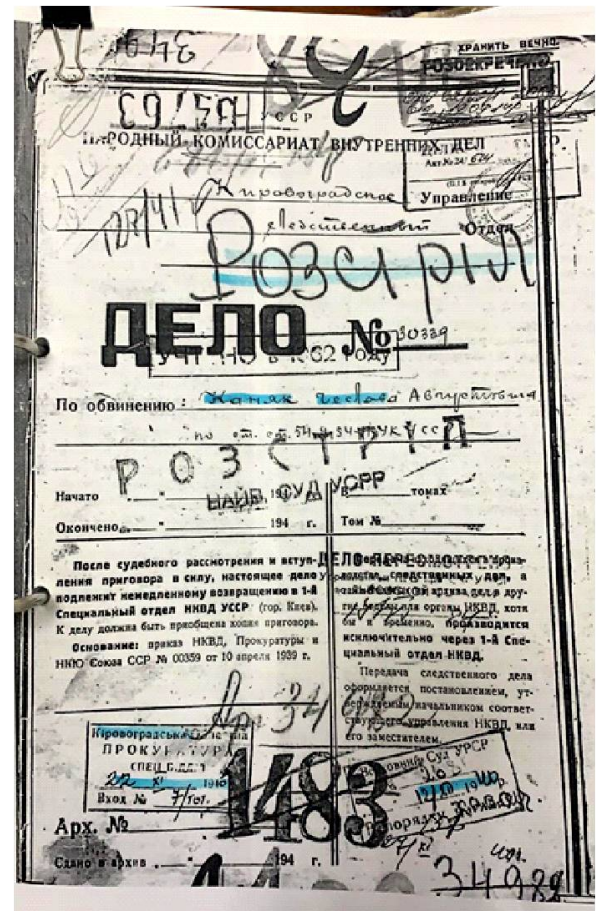

Title page of Criminal Archive Cheslav Kaniak

We should mention that the case did not contain the documents about description of the expropriated gold and jewelry. None of the court authority had an order about the gold. The investigators did not acknowledge the gold as the material evidence of the case. The deputy of a head of the UNKVD in Lviv district, Lieutenant of state security Krymian in the presence of a member of the NKVD of the
USSR, senior Lieutenant of state security Libenson provided the search and gold expropriation.

Cheslav Kaniak was executed personally by the head of the UNKVD in Kirovograd district, Lieutenant Rosov at the presence of the head of the UNKVD in Kirovograd district, Captain Neborakov and the deputy of a prosecutor for the special crimes Morozov at 24.00 on March $24^{\text {th }}$, 1941. A record with the stamp of top secret was composed in two copies. The place of burial is unknown.

The archival criminal case 34982 entered to the department of rehabilitation of the Security Service of Ukraine in Lviv Region on December $12^{\text {th }}, 1994$. The relatives were not found.

The deputy of a prosecutor in Lviv Region V.M. Myronovych endorsed the decision about rehabilitation on January $12^{\text {th }}, 1995$. The case was disclosed on $19.09 .2014^{16}$.

\section{Conclusions}

Overcoming the consequences of totalitarianism is unthinkable without the opening of the archives that contain information about the regime's crimes. It was particularly related to the archives of the repressive authorities that secured the existence of totalitarian states as well as meticulously collected information about anti-Soviet attitudes in society to strangle any opposition. The report of the International Council of Archives prepared for the UNESCO, regarding the special value of such documents, mentioned the following: "Solely the archives, primarily the police and service of intelligence archives that controlled people were able to depict the hidden social conflicts typical for such regimes. In contrast to the public image that endeavored to represent such regimes, their true nature could be discovered in the files and records of security service" (Gonzalez, 2010). Presented archival criminal cases of Chrzontovskyi Zigmund Yanovych, Bogdanovych Adam Stanislavovych, Kaniak Cheslav Avgustovych have demonstrated how merciless, ignored any norms about human rights, the Soviet repressive machine worked in the $20^{\text {th }}$ century. Furthermore, the ease of losing material evidence and ignoring them (as it was with the gold for financing UAS activity) was also described, wherein the fate of the arrested had been decided in advance. The funds of party cash boxes and the future oligarchs could potentially be established from such "lost evidence".

Moreover, one crucial conclusion concerns unlimited trust to the church of the ordinary parishioners as well as all who was determined to confront the system. A priest was an example of decency, honesty and patriotism. It is therefore not surprising that people appealed for them in such tough questions as financing of the underground work.

\section{REFERENCES}

Artizov, A. N. (ed.) (2012). Ukrainskiye natsionalisticheskiye organizatsii $v$ gody Vtoroy mirovoy voyny. Dokumenty. Vol. 1: 1939-1943. Moscow: Rossiyskaya politicheskaya entsiklopediya (ROSSPEN), $878 \mathrm{~s}$. Retrieved from http://archives.ru/ library/ukrainian-nationalist-organization-second-world-warvolume-1/files/assets/common/downloads/publication.pdf (In Russian).

Dashkevych, Ya. (1997). Obyektyvne i subyektyvne v prosopohrafiyi. Ukrayinskyy biohrafichnyy slovnyk: istoriya i problematyka stvorennya. Paper proseeding. (Lviv, October, 8-9 1996): 40-47 (In Ukrainian).

${ }_{16}$ САЗ УСБУ у Львівській області (Security Service of Ukraine in Lviv District). Архівна кримінальна справа П-34763. (Archive Supply Sector (ASS) the Security Service of Ukraine in Lviv district. Archive criminal case). KHC. 298 c. 
Gonzalez, Quintana Antonio (2010). Arkhivy sluzhb bezpeky kolyshnikh represyvnykh rezhymiv. Report for UNESCO of the International Council of Archives. Access to archival documents: law and practice. Kharkiv: Human Rights.

Hayuk, I. Ya. (2019). Osoblyvosti formuvannya etnokulturnoyi samosvidomosti virmen na ukrayinskykh zemlyakh. Mystetstvoznavchi zapysky. 35: 3-8. Retrieved from http://journals.uran.ua/mz/article/download/179397/181314 (In Ukrainian).

Kolakowski, Piotr (2002). NKWD i GRU. Na ziemiach Polskich 1939-1945. Warszawa: Dom wydawniczy Bellona, 388 s. (In Polish)

Kotarska, Elżbietą (1998). Proces czternastu. Oficyna wydawnicza Volumen. Warszawa, 299 s. (In Polish).

Levyk, B., \& Skorniewski, M. (2019). "The Case of Fourteen" and the Polish Anti-Soviet Underground in Lviv during 1939-1941. Skhid. 6(164), 16-22. DOI: http://dx.doi.org/10.21847/17289343.2019.6(164).185935

Mazur, Grzegorz \& Węgierski, Jerzy (1997). Konspiracja Lwowska 1939-1944. St ownik biograficzny. Wydawnictwo Unia, 256 s. (In Polish)

Osipyan, O. (2004). Dovhoochikuvana rekonstruktsiya "neochikuvanykh natsiy". Ukrayinskyy humanitarnyy ohlyad. 10: 155171 (In Ukrainian).

Starovoytenko, I. (2006). Prosopohrafiya: pidkhody do traktuvannya zmistu naukovoyi dystsypliny $v$ istoriohrafiyi. Spetsialni istorychni dystsypliny: pytannnya teoriyi ta metodyky. 13: 6.-27. Retrieved from http://resource.history.org.ua/publ/sid_2006_13_1_6 (In Ukrainian).

\section{LIST OF REFERENCES LINK}

Гаюк І. Я. Особливості формування етнокультурної самосвідомості вірмен на українських землях. Мистецтвознавчі записки. 2019. Вип. 35. С. 3-8. URL: http://journals.uran.ua/ mz/article/download/179397/181314
Дашкевич Я. Об'єктивне і суб'єктивне в просопографрії. Український біографрічний словник: історія і проблематика створення. Мат-ли наук.-практич. конфр. (Львів, 8-9 жовтня 1996 р.). Львів, 1997. С. 40-47.

Куінтана Антоніо Гонзалес. Архіви служб безпеки колишніх репресивних режимів. Звіт підготовлено для ЮНЕСКО від імені Міжнародної ради архівів. Доступ до архівних документів: законодавство і практика / Харківська правозахисна група. Харків: Права людини, 2010. С. 297.

Осіпян О. Довгоочікувана реконструкція "неочікуваних націй". Український гуманітарний огляд. Вип. 10. К., 2004. С. 155171.

Старовойтенко І. Просопографрія: підходи до трактування змісту наукової дисципліни в історіографії. Спеціальні історичні дисципліни: питанння теорії та методики. 2006. Вип. 13. С. 6.-27. URL: http://resource.history.org.ua/publ/ sid $2006 \quad 1316$

Украинские националистические организации в годы Второй мировой войны. Документы: в 2 т. Т. 1 : 1939-1943 / под ред. А. Н. Артизова. М.: Российская политическая энциклопедия (РОССПЭН), 2012. 878 c. URL: http://archives.ru/ library/ukrainian-nationalist-organization-second-world-warvolume-1/files/assets/common/downloads/publication.pdf

Kolakowski Piotr. NKWD i GRU. Na ziemiach Polskich 1939-1945. Dom wydawniczy Bellona. Warszawa, 2002. $388 \mathrm{~s}$.

Kotarska Elżbieta. Proces czternastu. Oficyna wydawnicza Volumen. Warszawa, 1998. $299 \mathrm{~s}$.

Levyk B., Skorniewski M. "The Case of Fourteen" and the Polish Anti-Soviet Underground in Lviv during 1939-1941. Skhid. 2019. 6(164). 16-22. DOI: http://dx.doi.org/10.21847/17289343.2019.6(164).185935

Mazur Grzegorz. Węgierski Jerzy. Konspiracja Lwowska 19391944. Słownik biograficzny. Wydawnictwo Unia, 1997. 256 s.

Богдан Левик,

Наиіональний університет "Львівська політехніка" (м. Львів, Украӥна)

e-mail: levykbs@gmail.com,ORCID 0000-0001-5100-0834

Маріуш Скорнсвський,

Люблінський католицький університет (м. Люблін, Польща)

e-mail:mskorn@o2.pl,ORCID 0000-0001-8307-3122

\section{ВІРМЕНИ ЛЬВОВА В КЕРІВНІЙ ЛАНЦІ ПОЛЬСЬКОї ПІДПІЛЬНОЇ ОРГАНІЗАЦІЇ "СОЮЗ ЗБРОЙНОї БОРОТЬБИ" 1939-1940 рр.}

Робота присвячена створенню "живих" образів історії на матеріалах конкретних історичних джерел (Я. Дашкевич). Через дослідження особистих тюремних та контрольно-наглядових справ трьох учасників польської підпільної організації "Союз збройної боротьби" - львівських вірмен Зигмунта Хржонстовського (інженер-агроном), Адама Богдановича (канонік вірмено-католицької капітули у Львові), Чеслава Каняка (пріора Домініканського монастиря) - автори намагаються встановити обставини засудження учасників польської підпільної організації та оприлюднити стандартні схеми радянського слідства та правосуддя 30-40-х років XX століття. Узагальнюючи матеріали (протоколи) допитів арештантів та свідків, автори показують, як радянські органи слідства та суду топтали права людини, "втрачали" та привласнювали матеріальні цінності, які вилучали в заарештованих. Також зроблено висновок про великий моральний авторитет вірменської католицької церкви у Львові та високий рівень патріотизму її представників.

Ключові слова: радянська окупація Львова; "Союз збройної боротьби"; вірмени-католики; Адам Богданович; Зигмунт Хржонстовський; Чеслав Каняк.

(C) Bogdan Levyk, Mariusz Skorniewski

Надійшла до редакції: 02.03.2020

Прийнята до друку: 17.03.2020 